Gut 1985, 26, 1385-1386

Case report

\title{
Enhancement of renal function with Ornipressin in a patient with decompensated cirrhosis
}

\author{
K LENZ, W DRUML, G KLEINBERGER, H HÖRTNAGL, A LAGGNER, \\ B SCHNEEWEIB, AND E DEUTSCH
}

From the I Department of Internal Medicine and Institute of Biochemical Pharmacology, University of Vienna, Vienna, Austria

SUMMARY An infusion with Ornipressin (8-ornithin vasopressin) in a patient with decompensated alcoholic liver cirrhosis increased urinary volume from $30 \mathrm{ml} / \mathrm{h}$ to $500 \mathrm{ml} / \mathrm{h}$, creatinine clearance from 24 to $65 \mathrm{ml} / \mathrm{min}$, and fractional sodium excretion from $0.86 \%$ to $11.1 \%$. Free water clearance decreased from $-10.2 \mathrm{ml} / \mathrm{h}$ to $-26.2 \mathrm{ml} / \mathrm{h}$ and noradrenaline plasma concentrations dropped from 2.04 to $1.37 \mathrm{ng} / \mathrm{ml}$. After stopping Ornipressin infusion all values returned to initial concentrations. Possible effects are an increase of renal blood flow secondary to an increase in arterial blood pressure, possibly potentiated by the vasodilatory effect of the fall in noradrenaline and/or angiotensin concentration.

The hepatorenal syndrome (HRS) is one of the most difficult to treat in hepatic insufficiency. Hepatorenal syndrome is defined as functional renal failure in which none of the usual causes of renal insufficiency is present and in which the kidneys are structurally normal. This disorder stubbornly resists attempts to improve renal function and usually ends in death. ${ }^{1}$

We report the case of a 38 year old woman with alcoholic liver cirrhosis, who was transferred to the intensive care unit because of decreasing renal function, which dramatically improved after infusion of Ornipressin (8-ornithin vasopressin, POR $8^{R}$ (Sandoz)).

\section{Case report}

Clinical examination on admission revealed ascites and hepatic coma grade II. Laboratory findings showed severe depression of hepatic function: prothrombin- $\left(\right.$ Normo-test ${ }^{\mathrm{R}}$ ) ratio: $0 \cdot 17$ (of normal), colloid osmotic pressure $10 \mathrm{mmHg}$, albumin concentration $1.9 \mathrm{~g} / 1$, bilirubin $1.6 \mu \mathrm{mol} / \mathrm{l}$. The renal

Address for correspondence: Dr K Lenz, 1 Medizinische Universitätsklinik, Lazarettgasse 14, A-1090 Wien, Austria.

Received for publication 22 February 1985 functin was depressed: creatinine clearance was $23 \cdot 5$ $\mathrm{ml} / \mathrm{min}$, fractional sodium excretion $0.86 \%$, despite continuous infusion of dopamine $(3 \mu \mathrm{g} / \mathrm{kg} / \mathrm{min})$ and spironolactone $(200 \mathrm{mg}$ twice daily for the last three months). Serum osmolality and concentrations of creatinine, potassium, and sodium are listed in Table 1.

After a four hour control period 18 units of ornipressin (POR $8^{R}$ ) were infused over the following four hours. There was a marked rise in systolic blood pressure from $92 \mathrm{mmHg}$ to $130 \mathrm{mmHg}$, systemic vascular resistance rose from 409 dyn sec $\mathrm{cm}^{-5}$ to 701 dyn sec $\mathrm{cm}^{-} 5$. Heart rate decreased

Table 1 Serum osmolality, concentrations of creatinine, potassium and sodium and noradrenaline before, during and after Ornipressin infusion

\begin{tabular}{lccc}
\hline & Before & $\begin{array}{l}2 \text { hours } \\
\text { after start }\end{array}$ & $\begin{array}{l}\text { 2 hours after } \\
\text { stopping ornipressin }\end{array}$ \\
\hline Osmolality & 288 & 288 & $299 \mathrm{mmol} / 1$ \\
Creatinine & 218 & 200 & $200 \mu \mathrm{mol} / 1$ \\
Potassium & 3.5 & 3.1 & $3.4 \mathrm{mmol} / 1$ \\
Sodium & 129 & 131 & $129 \mathrm{mmol} / 1$ \\
Noradrenaline & 2.04 & 1.37 & $1.95 \mathrm{ng} / \mathrm{ml}$ \\
\hline
\end{tabular}


from 94 to 80 beats/min, cardiac output from 11.31 to $9.3 \mathrm{l}$, stroke volume and left ventricular filling pressure remained nearly unchanged (Table 2). Urinary volume increased from $120 \mathrm{ml} /$ four hours to $2000 \mathrm{ml} /$ four hours, creatinine clearance rose from 25 to $68 \mathrm{ml} / \mathrm{min}$, free water clearance from -10.2 to $-26.2 \mathrm{ml} / \mathrm{hour}$, and fractional sodium excretion from $0.86 \%$ to $11.1 \%$ (Table 3 ). Noradrenaline concentration decreased from $2.04 \mathrm{ng} / \mathrm{ml}$ to 1.37 $\mathrm{ng} / \mathrm{ml}$ (Table 1).

After stopping Ornipressin infusion all values returned to near the control levels (Tables 1-3). The procedure was repeated on the following day with similar results. Ornipressin was then infused continuously $(1.5 \mathrm{U} / \mathrm{h})$ until the patient underwent successful liver transplantation.

\section{Discussion}

Although impairment in renal water and sodium excretion is a commonly encountered clinical problem in cirrhotic patients, the mechanisms responsible for this abnormality are uncertain and treatment is still very unsatisfactory. In a single case we found an increase of urinary volume, creatinine clearance and sodium excretion caused by an infusion of Ornipressin in a low dose ( $4.5 \mathrm{U} /$ hour). A different vasopressin derivate (2-phenylalanine 8-lysine vasopressin) caused a rise in blood pressure and increased renal blood flow only in those patients with cirrhosis. This suggested that the increase in glomerular filtration rate followed the increase in systemic pressure ${ }^{2}$ and we feel that this is the most likely explanation in this case. The effect on filtration rate might have been potentiated by renal vasodilatation. Noradrenaline output is known to increase in decompensated cirrhosis, ${ }^{3}$ and the reduction in this hormone shown in our case could, as suggested for PLV-2, ${ }^{1}$ cause dilatation of renal

Table 2 Haemodynamic data obtained 2 hours before, 2 hours after starting and 2 hours after the end of the Ornipressin infusion

\begin{tabular}{lccc}
\hline & Before & During & After ornipressin \\
\hline Heart rate & 94 & 80 & $101 \mathrm{beat} / \mathrm{min}$ \\
Systolic BP & 92 & 130 & $85 \mathrm{mmHg}$ \\
Pulmonary wedge pressure & 6 & 5 & $4 \mathrm{mmHg}$ \\
Cardiac output & $11 \cdot 3$ & $9 \cdot 3$ & $11 \cdot 4 \mathrm{l} / \mathrm{min}$ \\
Stroke volume & 121 & 117 & $113 \mathrm{ml}$ \\
Syst vasc resist & 409 & 701 & $391 \mathrm{dyn} / \mathrm{sec}^{-} / \mathrm{cm}^{-5}$ \\
\hline
\end{tabular}

Table 3 Urinary volume, creatinine clearance, osmolality and concentrations of creatinine, potassium and sodium in 4 hour periods before, during and after Ornipressin infusion.

\begin{tabular}{lccc}
\hline & Before & During & After Ornipressin \\
\hline Urinary volume & $0 \cdot 5$ & $8 \cdot 3$ & $0 \cdot 6 \mathrm{ml} / \mathrm{min}$ \\
Creatinine clear & 25 & 68 & $16 \mathrm{ml} / \mathrm{min}$ \\
Creatinine & 11000 & 1640 & $5210 \mu \mathrm{mol} / 1$ \\
Potassium & 56 & 15 & $33 \mathrm{mmol} / \mathrm{l}$ \\
Sodium & 55 & 119 & $91 \mathrm{mmol} / 1$ \\
Osmolality & 407 & 320 & $359 \mathrm{mmol} / \mathrm{l}$ \\
\hline
\end{tabular}

vessels. Moreover, Ornipressin, like body immersion of healthy subjects in water, ${ }^{4}$ causes a fall in plasma renin concentrations, redistribution of blood from the skin, and vasoconstriction. A good correlation has been shown between high plasma renin concentrations and a low glomerular filtration rate. ${ }^{5}$

A change in aldosterone activity cannot be the cause of the natriuresis, because the patient was on spironolactone throughout the experiment. The rise in urinary sodium concentration was not marked, and most of the increased fractional sodium excretion was almost certainly caused by an increased rate of filtration of plasma.

As this is a report of a single case, these results will need to be confirmed by further cases.

\section{References}

1 Cohn JN, Tristani FE, Khatri IM. Systemic and renal vasodilator effects of PLV-2 (octapressin) in man. Circulation 1969; 96: 413-7.

2 Kew MC, Varma RR, Sampson DJ, Sherlock S. The effect of octapressin on renal and intrarenal blood flow in cirrhosis of the liver. Gut 1972; 13: 193-296.

3 Ring Larsen H, Hesse B, Henriksen JH, Christensen NJ. Sympathetic nervous activity and renal and systemic hemodynamics in cirrhosis. Plasma norepinephrine concentration, hepatic extraction and renal release. Hepatology 1982; 2: 304-10.

4 Epstein M, Weitzman R, Preston S, DeNunzio AG. Relationship between plasma arginine vasopressin and renal handling in decompensated cirrhosis. Mineral Electrolyte Metab 1984; 10: 155-65.

5 Bichet DG, van Outten VJ, Schrier RW. Potential role of increased sympathetic activity in impaired sodium and water excretion in cirrhosis. $N$ Engl J Med 1982; 307: 1552-7. 